\title{
Juridical Review of Notary Role in Fiduciary Insurance in PT. Andalan Finance Indonesia (Nasmoco Credit) Semarang
}

\author{
Nurcahyo Pratomo Widodo ${ }^{1}$ and Lathifah Hanim²
}

Abstract. The purpose of this study was to analyze: 1) Implementation of the agreement with the Fiduciary PT. Andalan Finance Indonesia (Nasmoco Credit) Semarang. 2) The role of the Notary in the Deed of Fiduciary Manufacture PT. Andalan Finance Indonesia (Nasmoco Credit). 3) Obstacles and solutions in the manufacture of the Deed of Fiduciary PT. Andalan Finance Indonesia (Nasmoco Credit) Semarang.

This research is research with empirical juridical approach. Specification of the research is descriptive. In this study, researchers obtained the primary data sources through interviews and field research object of research Nasmoco Credit and Notary in Semarang. The secondary data obtained through literature.

The research results are: 1) Implementation of the agreement with the Fiduciary PT. Andalan Finance Indonesia (Nasmoco Credit) Semarang starting from the stage financing request of consumers, the application review consumer financing, the stages of recommendation, preparation of contract documents, disbursement of consumer financing, the stages of the agreement, the stages of the determination of insurance, the imposition of fiduciary, a deed to the notary and registration of fiduciary to fiduciary office. 2) The role of the Notary in the Deed of Fiduciary Manufacture PT. Andalan Finance Indonesia (Nasmoco Credit) Semarang is a Notary role in making authentic deed in the form of fiduciary deed in accordance with the provisions of the legislation as well as the notary office. 3) Barriers perceived by the notary that there are no obstacles for the data and procedures required by the notary had been prepared in full by both parties to undertake the financing agreement. This makes the notary does not have a bottleneck in the fiduciary deed. But for the problems in case of default Credit Nasmoco the path of deliberation, billing, administration subpoena or warning and the last way is a claim to court if there is no response from the Debtor.

Keywords: Fiduciary; Agreements; Credit

\section{Introduction}

Indonesia is one of the developing countries continue to seek development to the era of globalization. At the present time, the competition takes place strictly business in Indonesia. Business in Indonesia country growing very fast. Entrepreneurial increasingly emerging. Then, more and more facilitators offer a range of facilities that support the advancement of the business. One way is to offer a credit facility to finance companies that began to flourish in Indonesia.

In crediting one of the factors that also play an important role is the credit agreement. Without the loan agreement signed by the creditor and debtor, then there is no credit agreement. The credit agreement is usually followed by a security agreement, the credit agreement is the subject matter or principle, while the guarantee agreement is

1 Students Master of Notary Law, Sultan Agung Islamic University, Semarang email pratomonurcahyo@yahoo.com

${ }^{2}$ Faculty of Law Universitas Islam Sultan Agung 
an agreement means no followup or assesoir and expiry of the guarantee depends on the principal agreement. ${ }^{3}$

One of the collateral in credit agreements are fiduciary. Fiduciary guarantee is a guarantee of the trust that comes from the existence of a relationship between one human feeling with another human being in which they feel safe, so grows the confidence towards the interactions friend, to further provide their property as collateral to which they owe. Fiduciary roman times referred to as fiduciary cum creditore, means surrender as security alone is not transfer of ownership. ${ }^{4}$

Fiduciary no stipulated in the Law of Civil Law, and the birth of the implementation of the principle of freedom of contract under Article 1338 Book of the Law of Civil Law which states that all agreements made are valid for the parties to make and apply as enactment Act for the making. This means that each person allowed to make any agreement either already regulated by law and not regulated by law, so that many agreements appear in a new form that describes the purpose and will of the people who are always dynamic. ${ }^{5}$

In this fiduciary deed, must not be separated from the role of the Notary Public. Notary is a public official the only one authorized to make authentic act on all deeds, agreements and determination required by an act of law or by an interest desired to be stated in an authentic deed, ensure certainty the date, save aktanya and give grosse, copy and excerpt, all along the deed was also assigned or excluded to the officer or others. ${ }^{6}$ In carrying out its activities, Notary does not receive a salary or pension from being lifted. Though Notaries are appointed and dismissed but did not receive a salary or pension money from the government. Notary only receive emoluments from the people who have served or can provide services free of charge to those who can not. ${ }^{7}$ One car loan service providers in the city of Semarang is PT. Andalan Finance Indonesia (Nasmoco Credit) Semarang. With the implementation of corporate governance and risk management, AFI trusted by the creditors and get recognition from the financial industry as evidenced by obtaining the title of "EXCELLENT" years 2009 - 2018 a row of INFOBANK as a leading financial media. This gives the impetus for AFI to increasingly focus on developing services new and used car financing through investment financing, working capital, as well as a multipurpose supported skilled human resources, professional, and dedicated. ${ }^{8}$ Although AFI already received a designation as management company with a "very good", but did not rule would still be problems in the credit transaction which mostly use fiduciary.

Based on this background, lifted the title: " Juridical Review Of Notary Role In Fiduciary Insurance In PT. Andalan Finance Indonesia (Nasmoco Credit) Semarang". This study tries to answer issueson the implementation of the agreement with the Fiduciary PT. Andalan Finance Indonesia (Nasmoco Credit) Semarang, the role of the Notary Deed Making Fiduciary PT. Andalan Finance Indonesia (Nasmoco Credit) Semarang, barriers

\footnotetext{
3 Sutarno, 2004, Aspek-Aspek Hukum Perkreditan Pada Bank, Alfabeta, Bandung, p.98

4 J. Satrio, 2002, Hukum Jaminan Hak Jaminan Kebendaan Fidusia, PT. Citra Aditya Bakti, Bandung, p. 64

${ }^{5}$ Nurwidiatmo, 2011, Kompilasi Bidang Hukum Tentang Leasing, BPHN, Jakarta, p. 2

6 Soegianto, 2015, Etika Profesi dan Perlindungan Hukum Bagi Notaris, CV. Farisma Indonesia, Yogyakarta, p.2

7 Habib Adjie, 2008, Hukum Notaris Indonesia (Notaris Reglement), Erlangga, Jakarta, p. 31

8 https://www.andalanfinance.com, accessed March 24, 2019, at 16:27 pm
} 
and solutions in the manufacture of the Deed of Fiduciary PT. Andalan Finance Indonesia (Nasmoco Credit) Semarang.

\section{Research Methods}

The method used in this research is juridical empirical. Juridicalempirical ie research that focuses on the behavior of individuals or communities in connection with the law. ${ }^{9}$ Specification of the research is descriptive. Primary data were collected by interview. Type of interview used in this study using a free guided interview, is a combination of free and guided interview. ${ }^{10}$ Secondary data is data obtained from a review of the literature or the review of the literature or library materials related to the problem or research materials that are often referred to legal materials. ${ }^{11}$ Analysis of the data used in this study is a qualitative analysis.

\section{Discussion}

\subsection{Implementation of the agreement with the Fiduciary PT. Andalan Finance Indonesia (Nasmoco Credit) Semarang}

Stages of implementation of the financing agreement in PT. Andalan FinanceIndonesia (AFI) / Credit Nasmoco Semarang is as follows:

- Stages of Consumer Financing Request By Consumers

Consumer financing proposal stage begins with the filing of Consumer Financing Applications (APK) by prospective customers. Consumers according to PT. Andalan Finance Indonesia (Nasmoco Credit) Semarang divided into four individuals, entrepreneurs, professionals and companies. The provisions of the request for financing in Nasmoco Credit is: ${ }^{12}$

- Pure DP> $20 \%$ of the price of OTR, excluding installments 1st (first), insurance premiums, and administrative costs.

- To installments: at least 35\% of the income (fixed income), excluding overtime, bonuses or incentives.

- Stages Inspection Request Consumer Finance

Stages in the examination request for financing are: ${ }^{13}$

- Check and verify the data / document

Credit Analyst (CA) should check the documents of prospective customers. If the document is not complete then the document will be returned to the SP's complemented by a consumer finance applicant. If the CA stated that the document is complete then the data will be verified to be processed again. Verification of the principal aims of consumer financing to further ensure the feasibility of consumer financing, particularly relating to the validity of data from prospective customers.

\footnotetext{
9 Soerjono Soekanto dan Sri Mamadji, 2009, Penelitian Hukum Normatif: Suatu Tinjauan Singkat, Raja Grafindo Persada, Jakarta, p.1

10 Ibid, p. 84

${ }^{11}$ Mukti Fajar dan Yulianto, 2010, Dualisme Penelitian Hukum Normatif dan Empiris, Pustaka Pelajar, Yogyakarta, p. 156

12Interview with Mr. Isaac, Staff Sales Manager Nasmoco Credit, June 14, 2019

${ }^{13}$ Interview with Mr. Agus staff Nasmoco Credit Credit Analyst, June 14, 2019
} 
- The initial analysis of consumer financing (scorecard)

The initial analysis of consumer financing is intended to see whether an applicant deserves the consumer finance consumer financing or not and this analysis can provide an indication of whether a Credit Analyst (CA) needs to conduct a survey or analysis of additional requirements to the existence of the applicant's consumer financing. The survey in question is by way of a Credit Analyst (CA) come directly to the applicant's residence consumer financing to determine how much the applicant's ability financially consumer financing. Against any prospective customers who followed up with field verification or surveys, CA must complete and attach the visit reports in the consumer financing application file. Summary results of survey conducted verification or become part of the final consideration before settling on consumer financing decisions.

- Stages Recommendations

After conducting a thorough consideration and consumers have completed all the requirements of consumer financing, Credit Analyst (CA) to the final stage to recommend the approval or rejection to the Branch Manager or Sales Manager or $\mathrm{HR}$ has the authority to take decisions.

- Recommendation rejected if this happens of course after the scorecard and obtained an indication of credit decisions with a bad rating.

- Recommendation is accepted, this means that the rating obtained in the scorecard is $\mathrm{A}, \mathrm{B}$ or $\mathrm{C}$, if it obtained an $\mathrm{A}$ rating this case means the recommendation is given directly without conducting the survey again, whereas if the rating of $B$ and $C$ is still possible to do a survey in accordance analyzes obtained by Credit Analyst. After that CA will create consumer financing proposal and seek approval from the General Manager and Director of Operations, after approval then make the Consumer Financing Agreement Letter (SPK) for the loan application approved.

- Stages Contract Document Preparation

In the preparation phase the contract documents, Credit Administration then must complete the Letter of Approval from the consumer finance (SPK), which is equipped with the deal number (ODL). Then Approval Letter consumer finance (SPK) and deal number (ODL) is sent to the car dealer who previously designated by the consumer. Consumers signed agreements consumer finance and three receipts blank that has been provided by the Credit Administration, and Credit Administration to prepare a statement of the dealer, this letter in the form of a statement of surrender reg car, having signed the letter of Credit Administration sends Purchase Order Vehicle (PO) to the consumer, if the consumer has received the vehicle and sign the letter, then handed over to the Credit Administration again to be examined again these documents, in order to determine which documents were incomplete.

- Consumer finance Liquefaction Stages

After all processes and complete documents mentioned above, the application for loan financing can already be disbursed, Credit Administration also enter data for the consumer vehicle insurance, and coordinate payment and delivery of the policy to the insurance company designated and with the approval by the consumer.

- Stages Raw Agreement on the Financing Agreement 
Agreements of this type, content and requirements made by the PT.AFI (Nasmoco Credit) Semarang set forth in a written agreement that will be signed by the parties make an agreement. This agreement was made with the usual format, but most of the requirements have been standardized before being used in a business transaction, but certain parts are still open to negotiations that are integrated into a unified treaty. Certain parts that can still be changed, for example about the length of the loan term, the date of the installment, objects that serve as collateral, and so on. ${ }^{14}$

- Determining Stages Insurance in Consumer Financing Agreement

As we know that one of the elements that is always inherent in each financing agreement is the risk, the risk of loss and damage in connection with the object of financing according to the division of interests in a consumer financing agreement may be delegated to the consumer, then the emotion is determined insurance.

- Imposition stages Fiduciary On Consumer Finance Company in PT. Andalan Finance Indonesia

Consumer finance company PT. Andalan Finance Indonesia (AFI) (Credit Nasmoco) Semarang in practice the imposition of financial guarantees consumers are not bound or can be conditioned using a fiduciary or not, with the following criteria:

- When consumers take out financing under Rp.200,000,000, - are not subject to the fiduciary security, but if the consumer does not look good / have bad goodwill, PT. AFI directly fiduciated.

- If consumers take over the financing Rp.200,000,000, - PT. AFI directly fiduciated of early agreement.

If consumers want to pick up the financing under Rp.200,000,000., - the part of consumers to find out your wife / husband made a power of attorney to the PT. Andalan Finance Indonesia (Nasmoco Credit) The registered Semarang to the Notary.

In practice the above it can be seen that the implementation of the provision of fiduciary does not comply with the Act No. 42 of 1999, should the fiduciary agreement done by making the notary deed, before a notary, in the manufacturing operations fiduciary be notarized to be attended by the PT. AFI (Nasmoco Credit) Semarang and the consumer, so that if the conditions are not met are considered null and void the agreement that led to the PT. AFI can not seizing collateral.

Fiduciary implementation agreement for motor vehicle financing company governed by the Regulation of the Minister of Finance of the Republic of Indonesia Number 130 / PMK.010 / 2012 concerning the Registration Fiduciary Company For Consumer Financing Financing options for motor vehicles with Imposition Fiduciary.

This regulation aims to provide legal certainty for companies and consumer financing in connection with the surrender of property rights to the motor vehicle of consumer trust (fiduciary) to the finance company, so it needs to be registered at the registration office fiduciary fiduciary, as in Article $1:^{15}$

\footnotetext{
${ }^{14}$ Interview with Mr. Alvin, Staff Branch Manager Nasmoco Credit, June 14, 2019

15 Article 1 Regulation of the Minister of Finance of the Republic of Indonesia Number 130 / PMK.010 / 2012 concerning the Registration Fiduciary Share Financing Company
} 
- Financing companies that conduct consumer financing for motor vehicles with the imposition of fiduciary must register fiduciary referred to in Fiduciary Registration Office, in accordance with Law governing the fiduciary.

- Registration of fiduciary obligations as mean in paragraph (1) shall also apply to finance companies that do:

- Vehicle consumer financing based on Islamic principles

- Consumer financing vehicles whose financing comes from forwarding financing (channeling) or cofinancing (joint financing).

The normative regulation provides legal certainty according to the theory of legal certainty that the rules are made and enacted exactly as set out clear and logical. Registration fiduciary to the fiduciary registration office to do the longest was 30 days

\subsection{The role of the Notary Deed Making Fiduciary in PT. Andalan Finance Indonesia (Nasmoco Credit) Semarang}

Preparation of Deed of Fiduciary PT. Andalan Finance Indonesia (Nasmoco Credit) a Financing Agreement Semarang done when both parties have reached an agreement in credit financing. Once both parties agree, then both facing to the Notary for the preparation of fiduciary deed. ${ }^{16}$ In terms of consumer financing agreement between PT. AFI (Nasmoco Credit) Semarang with consumers set out in Article 5 of Act No. 42 of 1999 concerning the imposition of fiduciary agreements require the creation of objects with fiduciary, by notarial deed. The only public official who has the authority right to make agreements on goods with the imposition of fiduciary just Notary, in other words that a guarantee agreement on goods with the fiduciary must shall be notarized.

Notary is a public official by the public (including clients in the form of finance companies / banks) are considered to understand even master the law therefore must master all the laws and then not merely entitled, but obliged to provide legal advice to clients primarily on the plan-making deed and everything with the correct legal action in connection with the willingness client / Applicant.

The role of the notary in the manufacture of material warranty deed (fiduciary) according to the authority in Article 15 paragraph (1) No. 2 of 2014 on The Notary Specifications office at:

- Ensuring sound creation date

In this case are in accordance with the date of realization of finance and finance that brings the office notary files to be made a material warranty deed (fiduciary). Date of fiduciary deed in accordance with the date of signature of finance. Time used in the manufacture of material warranty deed (fiduciary) that is dependent on the number of certificates made, if one day there was a 100 deed to be made then the time it takes two to three days. While the validity period fiduciary deed was valid until the goods payments in full. ${ }^{17}$

- How to save deed

How to save the certificate that has been made by a notary public notary office that had no place to store certificates especially those that have been made and the

\footnotetext{
${ }^{16}$ Interview with Notary Bambang Soegianto, dated June 21, 2019

17 Novia Asmita, 2018, Peran Notaris Dalam Pembuatan Akta Jaminan Kebendaan Studi Pada Kantor Notaris Elviani, S.H.,M.Kn Kabupaten Gowa, Jurnal FIS Universitas Negeri Makassar, South Celebes
} 
name lemati tembat deed all the certificates that have been created are stored in and can only be issued if there is a problem the client premises. ${ }^{18}$

- Procedures for granting grosse

Procedures for granting grosse in deed fiduciary ie notary issued grosse deed made the remarks on the minutes of the deed of the recipient grosse and at the end and cover deed is then given as grosse first to name the person who asked for it and for whom grosse issued and the date of the expenditure deed and the deed every month there are numbers each month certificate and the certificate number is replaced by restarting the deed number one and so on until closing months and notaries have a special book that the deed numbers regularly.

- How to delivery of a copy, and official copies

Procedures for granting copies and official copies in Kline ie when all the paperwork has been completed in accordance with what is requested by a notary and all the parties concerned are already doing autographs diakta then copy and official copies provided to the client because it is in accordance with the procedure and if it is not procedures meet the notary did not dare to give a copy of the deed and quotations to clients.

\subsection{Obstacles and solutions in the manufacture of the Deed of Fiduciary in PT. Andalan Finance Indonesia (Nasmoco Credit) Semarang}

The obstacles in the deed of fiduciary in PT Andalan Finance Indonesia (Nasmoco Credit) are perceived by the notary that there are no obstacles for the data and procedures required by the notary had been prepared in full by both parties to undertake the financing agreement. This makes the notary does not have a bottleneck in the fiduciary deed. ${ }^{19}$ There are several measures taken by the PT. AFI (Credit Nasmoco Semarang in the event of default, is to make efforts include consultation, billing, provision of summons or warning, and the last Lawsuit To Debtors (Customers). Based on consumer finance dispute resolution measures already described, PT. AFI (Nasmoco Credit) Semarang continue to rely on the settlement amicably. In a sense if there is still the consensus that can be achieved then it will not just apply to the lawsuit, but if it is felt indeed could not be solved amicably and already there are indications of an unlawful act, PT. AFI Semarang to act decisively to resolve it through legal channels.

\section{Closing}

\subsection{Conclution}

Based on the description above conclusions in this study are:

- Implementation of the agreement with the Fiduciary PT. Andalan Finance Indonesia (Nasmoco Credit) Semarang starting from the stage of consumer financing request with form filling Consumer Financing Applications (APK) and meets the requirements of completeness. The second stage of examination Request Consumer Finance, step is conducted after the prospective consumers apply for consumer finance by

\footnotetext{
18 Interview with Notary Bambang Soegianto, June 21, 2019
}

${ }^{19}$ Interview with Notary Bambang Soegianto, June 21, 2019 
completing the form APK provided by PT. AFI (Nasmoco Credit) Semarang, attached with the necessary documents. The third stage is the stage recommendation, made after consideration of a thorough and consumers have completed all the requirements of consumer financing, Credit Analyst (CA) to the final stage to recommend the approval or rejection to the Branch Manager or Sales Manager or HR has the authority to take decisions. The fourth stage is a Contract Document Preparation, Disbursement fifth stage of consumer financing, the stages of the agreement, the stages of the determination of insurance and loading stages fiduciary, a deed to the notary and registration of fiduciary to the fiduciary office.

- The role of the Notary Deed Making Fiduciary PT. Andalan Finance Indonesia (Nasmoco Credit) Semarang is a Notary role in making authentic deed in the form of fiduciary deed in accordance with the provisions of the legislation as well as the notary office. The role of the notary in the deed ffidusia according to the authority in Article 15 paragraph (1) No. 2 of 2014 on the mengkhusus otaris positions on guaranteeing the date of a deed, to save deed, grosse granting procedures and the provision of copies, and official copies.

- Obstacles and solutions in the manufacture of the Deed of Fiduciary PT. Andalan Finance Indonesia (Nasmoco Credit) Semarang is perceived by the notary that there are no obstacles for the data and procedures required by the notary had been prepared in full by both parties to undertake the financing agreement. This makes the notary does not have a bottleneck in the fiduciary deed. But for the problems in case of default Credit Nasmoco the path of deliberation, billing, administration subpoena or warning and the last way is a claim to court if there is no response from the Debtor.

\subsection{Suggestion}

- The government should further reinforce regulations on consumer finance agreements where the latter offenders given consumer financing firm sanctions.

- PT. Andalan Finance Indonesia Semarang also should be more careful in determining who will be the kensumennya so that violations of consumer financing are serious does not happen in the future.

- For consumers also need to understand about the rules of fiduciary, so that in case things are not desirable consumers are not easily duped by those who tidka responsible.

\section{Bibliography}

\section{Book}

[1] Achmad Sulchan, Sukarmi, Ari Widiyanto, 2017, Akta Notaris Menggunakan Media Elektronik, SINT Publishing, Kendal

[2] Amiruddin, 2012, Pengantar Metode Penelitian Hukum, Rajagrafindo Persada, Jakarta

[3] Herlien Budiono, 2013, Dasar Teknik Pembuatan Akta Notaris, PT. Citra Aditya Bakti, Bandung

[4] Mulyoto, 2016, Legal Standing, Cakrawala Media, Yogyakarta 
[5] Mulyoto, 2012, Perjanjian (Tehnik, cara membuat, dan hukum perjanjian yang harus dikuasai), Cakrwala Media, Yogyakarta

[6] Habib Adjie, 2008, Hukum Notaris Indonesia (Notaris Reglement), Erlangga, Jakarta

[7] https://www.andalanfinance.com

[8] J. Satrio, 2002, Hukum Jaminan Hak Jaminan Kebendaan Fidusia, PT. Citra Aditya Bakti, Bandung

[9] Mukti Fajar dan Yulianto, 2010, Dualisme Penelitian Hukum Normatif dan Empiris, Pustaka Pelajar, Yogyakarta

[10] Munir Fuady, 2003, Jaminan Fidusia, PT.Citra Aditya Bakti, Bandung

[11] Novia Asmita, 2018, Peran Notaris Dalam Pembuatan Akta Jaminan Kebendaan Studi Pada Kantor Notaris Elviani, S.H.,M.Kn Kabupaten Gowa, Jurnal FIS Universitas Negeri Makassar, Sulawesi Selatan

[12] Nurwidiatmo, 2011, Kompilasi Bidang Hukum Tentang Leasing, BPHN, Jakarta

[13] Rachmadi Usman, 2008, Hukum Jaminan Keperdataan, Sinar Grafika, Jakarta

[14] Rachmadi Usman, 2013, Hukum Kebendaan, SInar Grafika, Jakarta

[15] Salim H. S., 2010, Perkembangan Teori Dalam Ilmu Hukum, Rajawali Pers, Jakarta

[16] Salim HS, 2016, Teknik Pembuatan Akta Satu, PT. Rajagrafindo Persada, Jakarta

[17] Soegianto, 2015, Etika Profesi dan Perlindungan Hukum Bagi Notaris, CV. Farisma Indonesia, Yogyakarta

[18] Soerjono Soekanto dan Sri Mamadji, 2009, Penelitian Hukum Normatif: Suatu Tinjauan Singkat, Raja Grafindo Persada, Jakarta

[19] Sutan Remy Sjahdeini, 2009, Kebebasan Berkontrak dan Perlindungan Yang Seimbang Bagi Para Pihak Dalam Perjanjian di Indonesia, PT. Pustaka Utama Graffiti, Jakarta

[20] Sutarno, 2004, Aspek-Aspek Hukum Perkreditan Pada Bank, Alfabeta, Bandung

\section{Legislation}

[1] Constitution of the Republic of Indonesia of 1945

[2] Code of Civil law

[3] Act No. 42 of 1999 on Fiduciary

[4] Regulation of the Minister of Finance of the Republic of Indonesia Number 130 / PMK.010 / 2012 concerning the Registration Fiduciary Share Financing Company

[5] Act No. 02 of 2014 concerning Notary

[6] Regulation of the Minister of Justice and Human Rights of the Republic of Indonesia Number 4 of 2014

[7] Government Regulation No. 21 of 2015 regarding Registration Procedures and Fees Fiduciary Fiduciary Deed Making

\section{Journals}

[1] Irsyadul Anam Malaba, "Pluralitas Organisasi Notaris di antara Hak, Kebutuhan, Inefiensi dan Tafsir Pemerintah". Jurnal Renvoi, Nomor 2. 26. III Third year of 2005 
[2] Ima Erlie Yuana, "Tanggung jawab Notaris Setelah Berakhir Masa Jabatannya Terhadap Akta yang Dibuatnya Ditinjau dari Undang-undang Nomor 30 Tahun 2004 tentang jabatan Notaris", Thesis of Master of Notary Law, Post graduate program, Diponegoro

[3] Muhammad Hilmi, Anis Mashdurohatun, "Akibat Hukum Jaminan Fidusia Yang Tidak Didaftarkan Menurut UU Nomor 42 Tahun 1999", Jurnal Akta Vol. 4 No. 3 September 2017

[4] Novia Asmita, 2018, "Peran Notaris Dalam Pembuatan Akta Jaminan Kebendaan Studi Pada Kantor Notaris Elviani, S.H.,M.Kn Kabupaten Gowa", Jurnal FIS Universitas Negeri Makassar, South Celebes 